\title{
Entomological surveillance of Chagas disease in Berilo municipality, Jequitinhonha Valley, State of Minas Gerais, Brazil
}

\author{
Vigilância Entomológica da doença de Chagas no município de Berilo, \\ Vale do Jequitinhonha, Estado de Minas Gerais, Brasil
}

\author{
Girley Francisco Machado de Assis ${ }^{1}$, Bernardino Vaz de Mello Azeredo², \\ David Gorla ${ }^{3}$, Liléia Diotaiuti ${ }^{4}$ and Marta de Lana ${ }^{1,5}$
}

\begin{abstract}
This study aimed to evaluate the Chagas Disease Control Program which has operated since 1982 in the municipality of Berilo in the Jequitinhonha Valley, Minas Gerais, Brazil, based on evaluation of 5,242 domiciliary units (DUs) and 7,807 outbuildings over an eight-year period of epidemiological surveillance implanted in 1997. A total of 391 triatomines (280 Panstrongylus megistus and 111 Triatoma pseudomaculata) were captured, indicating the continued predominance of the former species. However, Triatoma pseudomaculata is clearly becoming more important in this region, with intradomiciliary colonies being detected in recent years. Entomological parameters, such as dispersion (17\%) and intradomiciliary infestation (0.15\%) indices, are compatible with the results of the epidemiological surveillance. The majority of DUs were of construction type A (plaster over bricks) or C (plaster over adobe). Twenty-five percent of the inhabitants of the DUs infested by triatomines were reactive in ELISA, IHA and IIF tests for Trypanosoma cruzi antigens.
\end{abstract}

Key-words: Entomological surveillance. Chagas disease. Panstrongylus megistus. Triatoma pseudomaculata. Serological survey.

\section{RESUMO}

O objetivo deste estudo foi avaliar o Programa de Controle de doença de Chagas instalado desde 1982 no município de Berilo, Vale do Jequitinhonha, MG, Brasil, baseado na avaliação de 5.242 unidades domiciliares e 7.807 anexos após oito anos de implantação da vigilância epidemiológica que ocorreu em 1997. Um total de 391 triatomíneos (280 Panstrongylus megistus e 111 Triatoma pseudomaculata) foram capturados, indicando o contínuo predomínio da primeira espécie. No entanto, Triatoma pseudomaculata está claramente se tornando mais importante nesta região, com colônias intradomiciliares sendo detectadas recentemente. Parâmetros entomológicos, como os índices de dispersão (17\%) e infestação intradomiciliar (0,15\%), são compatíveis com a fase de vigilância epidemiológica. A maioria das UDs apresenta padrão de construção tipo A (tijolo com reboco) e C (adobe com reboco). Dentre os habitantes das unidades domiciliares infestadas por triatomíneos, $25 \%$ apresentavam testes reativos na ELISA, HAI e IFI para antígenos de Trypanosoma cruzi.

Palavras-chaves: Vigilância entomológica. Doença de Chagas. Panstrongylus megistus. Triatoma pseudomaculata. Inquérito sorológico.

Chagas disease or American trypanosomiasis is the result of infection by the flagellate protozoan Trypanosoma cruzi, (Kinetoplastida, Trypanosomatidae). According to the World Health Organization, this disease is endemic to the Neotropics, where 13 million people from 15 countries are infected, showing

1. Núcleo de Pesquisas em Ciências Biológicas, Universidade Federal de Ouro Preto, Ouro Preto, MG. 2. Fundação Nacional da Saúde, Ministério da Saúde, Belo Horizonte, MG. 3. Centro de Investigaciones Cientificas y Transferencia Tecnolgica, Anillaco, La Rioja, Argentina. 4. Centro de Pesquisa René Rachou, Fundação Instituto Oswaldo Cruz, Belo Horizonte. MG. 5. Departamento de Análises Clínicas, Escola de Farmácia, Universidade Federal de Ouro Preto, Ouro Preto, MG.

Financial support: FAPEMIG, CNPq, SESU/MEC, UFOP.

Address to: Dr. Girley Francisco Machado de Assis. Núcleo de Pesquisas em Ciências Biológicas/ICEB/UFOP, Campus Universitário Morro do Cruzeiro, 35400-000 Ouro Preto, MG, Brasil.

Phone/Fax: 5531 3559-1680

e-mail: girleyfrancisco@nupeb.ufop.br

Recebido para publicação em 28/08/2009

Aceito em 17/11/2009 an annual incidence and mortality of 200,000 and 50,000 cases, respectively. It is estimated that approximately 100 million people remain exposed to the risk of infection ${ }^{21}$.

The triatomine species of major epidemiological importance in Minas Gerais is Panstrongylus megistus, a species endemic to this region that presents a great capacity to invade and colonize houses and their peridomiciles ${ }^{10}$. In contrast, Triatoma infestans was introduced to this state via São Paulo in the early $20^{\text {th }}$ century and subsequently disseminated northwards ${ }^{3}$.

In 1940, Panstrongylus megistus wasthetriatominespeciesmost often captured in Minas Gerais (79.8\%), followed by Triatoma sordida (9.7\%) and Triatoma infestans $(9.3 \%)^{10}$. Although by that time Triatoma infestans was widely dispersed in southeastern Brazil, including the "Triângulo Mineiro" region, it was not recorded until 1950 in the north and northeast of Minas Gerais, which includes the Jequitinhonha Valley ${ }^{1415}$. In the same year, Triatoma infestans was the triatomine species most often captured in Brazil (70.8\%), with a 
high prevalence of infection with Trypanosoma cruzi ${ }^{14}$. In 1951, Panstrongylus megistus was the only vector species captured inside houses in Minas Novas, which at that time was part of the municipality of Berilo ${ }^{15}$.

The first attempts to control Chagas disease vectors in the Jequitinhonha Valley were conducted during the 1960s by the National Department of Rural Endemics (Departamento Nacional de Endemias Rurais, DNERu). From 1970 to 1980, vector control was under the responsibility of the Jequitinhonha Valley Development Commission (Comissão de Desenvolvimento do Vale do Jequitinhonha, CODEVALE) and Regional Health Management (Gerência Regional de Saúde, GRS - RHM) based in Diamantina. In 1982, the national vector control program was implanted in this region and conducted in parallel with activities of the national triatomine survey. Afterwards, all houses in Berilo were sprayed with residual insecticides, followed by regular reevaluations and selective spraying of the remaining positive houses. Based on the positive results obtained with this program, epidemiological surveillance was implanted in 1997.

The constant presence of Panstrongylus megistus in the peridomicile is considered to be an important link between the wild and domiciliary environment. Furthermore, the presence of other species considered up until now to be of secondary importance to Trypanosoma cruzi transmission in this region reinforces the need for reevaluation of the Brazilian National Chagas Disease Control Program (Programa de Controle da Doença de Chagas, PCDCh - CDCP) that was installed in Berilo eight years ago. Therefore, the objective of this study was to evaluate data gathered during epidemiological surveillance.

\section{MATERIAL AND METHODS}

Characteristics of the study area. Berilo (10 57'06"s; $42^{\circ} 27^{\prime} 56^{\prime \prime} \mathrm{W}$ ) is located at $401 \mathrm{~m}$ of altitude in the Jequitinhonha Valley region of northeastern Minas Gerais, $660 \mathrm{~km}$ from the state capital of Belo Horizonte. It has an area of $581.5 \mathrm{~km}^{2}$. According to the IBGE 2000 census, the total population is 12,979, of which $3,031(23.4 \%)$ live in the town itself and 9,948 (76.6\%) in the surrounding rural area, distributed among 30 communities. The predominant biome of this region is cerrado (savanna), characterized by a hot, semi-humid seasonal climate, with a mean annual temperature of $24^{\circ} \mathrm{C}$ and rainfall of $800-1,600 \mathrm{~mm}$ that is restricted to a few months of the year. Soils are generally very old, chemically poor and deep. This, together with the lack of governmental support for farmers, makes agriculture a difficult economic activity in this region.

History of the Chagas Disease Control Program. The earliest CDCP data referring to the triatomine survey and later evaluations were obtained by consulting documents belonging to the National Health Foundation (Fundação Nacional de Saúde, FUNASA - NHF).

After the implantation of epidemiological surveillance in Berilo, triatomines captured by the inhabitants in and around houses were sent to triatomine information posts (TIPs) installed at strategic points within the municipality. The insects were then sent to the regional laboratory in Diamantina, where they were classified according to species and evolutionary stage before being examined for the presence of Trypanosoma cruzi or similar flagellates. After notification, a health agent visited the house where the triatomine had been collected and a new search was conducted using flashlights and forceps to permit examination of hiding places for insects or their remains, such as exuviae, feces and urine.

When the notification was confirmed, all domiciliary units (DUs), including outbuildings, were sprayed with a pyrethroid insecticide. Triatomines captured in houses and peridomiciles were stored in different containers, labeled with data and their location and sent to the regional laboratory. The finding of nymphs in or around houses was interpreted as colonization.

Triatomine infestation survey. This survey was conducted between 02/16/05 and 01/13/06 in all DUs of the rural and urban areas of Berilo, based on routine procedures of the CDCP under the supervision of the Minas Gerais State Health Secretariat (SES-MG) and RHM of Diamantina. A daily research bulletin was produced containing the following information: 1) the municipality code; 2) the locality code; 3) name of the locality; 4) the house number; 5) name of the principal householder; 6) number of inhabitants; 7) number of outbuildings; 8) place of capture and 9) type of wall and roof. The work team constituted of a researcher (the first author of this article), a driver and four health agents who remained in the municipality throughout the survey period.

All Dus that presented triatomines in the intra- or peridomicile were sprayed with alpha-cypermethrin $\left(25 \mathrm{mg}\right.$ a.i. $\left./ \mathrm{m}^{2}\right)$. All the triatomines found were captured and transported to the laboratory for identification and examination. The following data were recorded: 1) triatomine species; 2) evolutionary stage and sex (if adult); 3) number and percentage of specimens infected by Trypanosoma cruzi; 4) place of capture (intra- or peridomicile) and 5) locality of origin.

Evaluation of the Chagas diseases control program. To evaluate the efficacy of the control program in Berilo following the implantation of epidemiological surveillance, entomological indicators were determined, as recommended by the World Health Organization - $\mathrm{WHO}^{51220}$. These permitted the calculation of: 1) dispersal index; 2) DU infestation index; 3) index of intraand peridomiciliary infestation; 4) index of natural infection by Trypanosoma cruzi; (5) intra- and peridomiciliary colonization indices; and 6) triatomine density.

Evaluation of building quality of the domiciliary units. All DUs inspected were classified according to building pattern, taking into account only the type of the wall, since all houses presented the roof covered with tiles. The DUs were classified as Type A: brick and tow, Type B: brick without tow, Type C: adobe with tow and Type D: adobe without tow.

Prevalence of Trypanosoma cruzi infection in inhabitants of triatomine-infested domiciliary units. To determine the index of human Trypanosoma cruzi infection, $3 \mathrm{~mL}$ of blood of all individuals living in the infested DUs were collected 
for serological tests. Blood was collected after the occupants had read and signed the free and informed consent form approved by the Ethical Committee of the René Rachou Research Center (Centro de Pesquisas René Rachou, CPqRR), FIOCRUZ, Belo Horizonte, (Process 007/02). The study thus complied with resolution number 196/1996 of the National Health Council for research involving humans.

Serological examinations of inhabitants of infested houses. All sera were analyzed by ELISA and indirect hemagglutination tests (IHA) plus the indirect immunofluorescence (IIF) test when necessary, as recommended by WHO and the Brazilian Ministry of Health ${ }^{11} 20$.

ELISA was performed according to Voller et $a l^{19}$, with sera diluted to 1:80, antigen concentration of $4.5 \mathrm{ug} / \mathrm{mL}$ and human anti-IgG conjugate labeled with peroxidase diluted 1:10,000. IHA and IIF were conducted using kits supplied by bioMériex and BioManguinhos, respectively, and manufacturer's recommendations were followed in each case.

Environmental changes. The activities of the CDCP in Berilo spanned almost four decades (from the early 1960s to 1997) prior to the installation of the epidemiological surveillance phase. During this period, the area underwent environmental changes that could have influenced the epidemiological situation through indirect effects on the insect vectors and/or the economic status of the local people. Environmental changes in the study area were examined using TM Landsat images for 1986 (Landsat 5 TM) and 2001 (Landsat 7 ETM+), using standard bands to calculate the Normalized Difference Vegetation Index (NDVI, amount of green biomass covering the ground), with a nominal spatial resolution of pixel size $30 \mathrm{~m}$. Although sensors were different, channels 3 and 4 used to calculate the NDVI were the same. The Landsat images were downloaded from the Global Land Cover Facility of Maryland University (http://glcf.umiacs.umd.edu/data/landsat/) and corresponded to the dates September 25, 1986 and September $10,2001$.

\section{RESULTS}

A total of 114 triatomines was sent to the Diamantina regional laboratory during the epidemiological surveillance activities in the municipality of Berilo. Most specimens were adults captured inside houses. The following species were identified: Panstrongylus megistus (46.5\%), Triatoma pseudomaculata (21\%), Panstrongylus geniculatus (18.4\%), Panstrongylus diasi (11.4\%), Triatoma vitticeps (1.8\%) and Triatoma sordida (0.9\%). Sixty-three specimens, equivalent to $55.3 \%$ of the insects captured, were examined for presence of Trypanosoma cruzi or similar flagellates. The rest of the specimens were either dead or dry. Only two (3.2\%) specimens were positive, both Panstrongylus megistus.

As shown in Figure 1, Panstrongylus megistus has been the predominant species since the initiation of the CDCP in Berilo in 1982. This species presents a great capacity for invading houses and is frequently encountered colonizing the intra- and peridomicile.

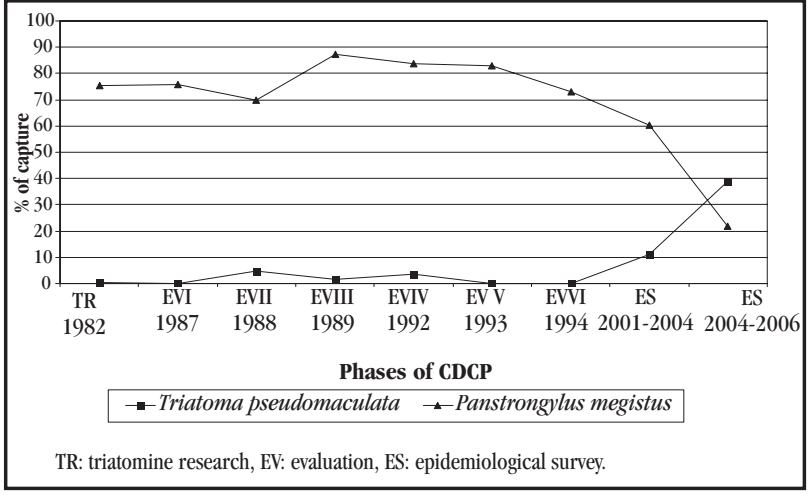

FIGURE 1

Percentages of Panstrongylus megistus and Triatoma pseudomaculata captured in different phases of the Chagas disease control program in Berilo municipality. TR: triatomine research, EV: evaluation, ES: epidemiological surveillance.

However Triatoma pseudomaculata, a species that was rarely present in the past, has increased significantly in the last two years, to such an extent that in 2005 it was the species most frequently reported by the local population.

In 2005, 5,242 (96\%) DUs and 7,807 outbuildings were inspected during the integrated triatomine research program in Berilo. Two hundred and twelve DUs were closed when visited and, therefore, were not included in the evaluation. Only one householder refused permission for his home to be searched for triatomines. Of the DUs inspected 1,385 (26.5\%) were in urban and 3,857 (73.5\%) in rural areas.

Triatomines were observed in 35 DUs (Figure 2) and 391 insects were captured. None of these was infected by Trypanosoma cruzi or similar flagellates. Two hundred and eighty

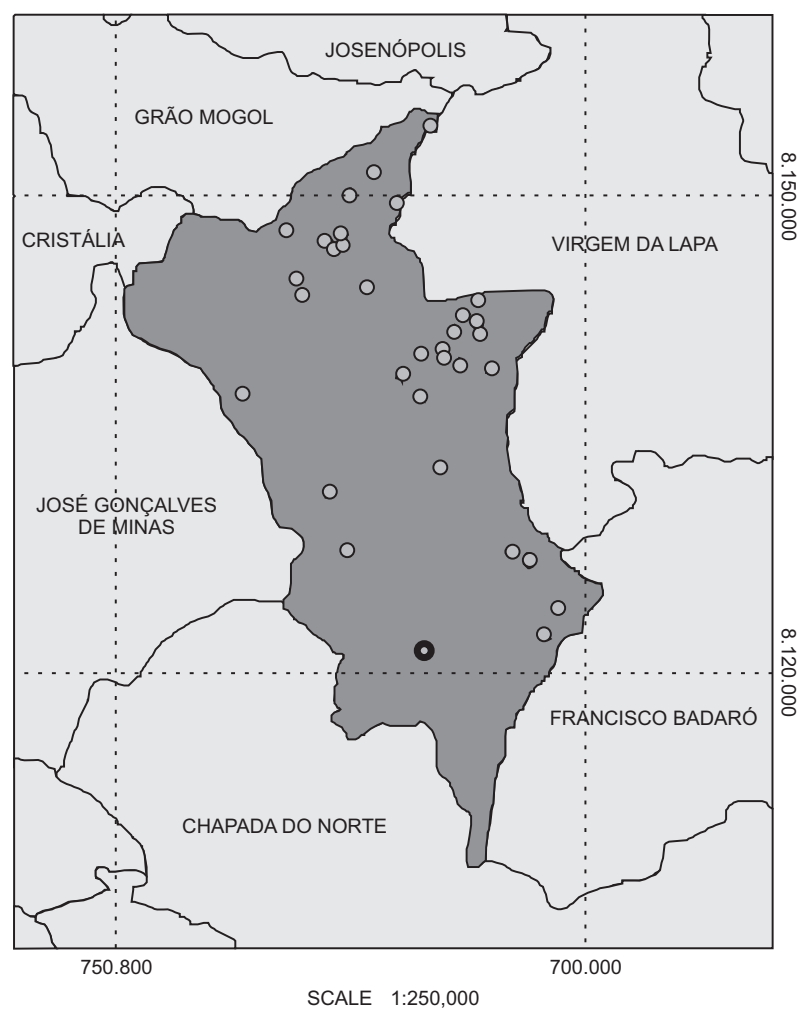

FIGURE 2

Distribution of domiciliary units infested by triatomines in Berilo municipality, Jequitinhonha Valley, Minas Gerais, during the integrated research program of 2005. 
specimens (72\%) were Panstrongylus megistus and 111 (28\%) Triatoma pseudomaculata (Table 1). Only one house was colonized by the latter species. Six specimens (three adults and three nymphs) of a total of approximately 100 insects captured in microhabitats associated with bats were examined, but none were verified as infected with flagellates. No specimens of Triatoma infestans were captured.

The majority of triatomines captured were nymphs (Table 2), particularly in the peridomicile. Most captures occurred in hen houses (Figure 3) and only a few triatomines were confirmed migrating to or colonizing houses.

TABLE 1

Triatominae captured during the integral research in Berilo municipality, Jequitinhonha Valley, MG, Brazil in 2005, according to species and place of capture.

\begin{tabular}{lrrrrrrr}
\hline \multirow{2}{*}{ Species } & \multicolumn{2}{c}{ Intradomicile } & & \multicolumn{2}{c}{ Peridomicile } & Total \\
\cline { 2 - 3 } & $\mathrm{n}$ & $\%$ & & $\mathrm{n}$ & $\%$ & $\mathrm{n}$ \\
\hline Panstrongylus megistus & 62 & 22.1 & & 218 & 77.9 & 280 \\
Triatoma pseudomaculata & 9 & 8.1 & & 102 & 91.9 & 111 \\
\hline Total & 71 & 18.2 & 320 & 81.8 & 391 \\
\hline
\end{tabular}

TABLE 2

Percentage of triatomines captured during the integral research in Berilo municipality, Jequitinhonha Valley, MG, Brazil in 2005, according to species and evolutionary stage.

\begin{tabular}{|c|c|c|c|c|c|c|}
\hline \multirow[b]{3}{*}{ Evolutionary stage } & \multicolumn{4}{|c|}{ Species } & & \\
\hline & \multicolumn{2}{|c|}{$\begin{array}{c}\text { Panstrongylus } \\
\text { megistus }\end{array}$} & \multicolumn{2}{|c|}{$\begin{array}{c}\text { Triatoma } \\
\text { pseudomaculata }\end{array}$} & \multicolumn{2}{|c|}{ Total } \\
\hline & $\mathrm{n}$ & $\%$ & $\mathrm{n}$ & $\%$ & $\mathrm{n}$ & $\%$ \\
\hline Male & 22 & 7.9 & 15 & 13.5 & 37 & 9.5 \\
\hline Female & 46 & 16.4 & 11 & 9.9 & 57 & 14.5 \\
\hline Nymph & 212 & 75.7 & 85 & 76.6 & 297 & 76.0 \\
\hline Total & 280 & 100.0 & 111 & 100.0 & 391 & 100.0 \\
\hline
\end{tabular}

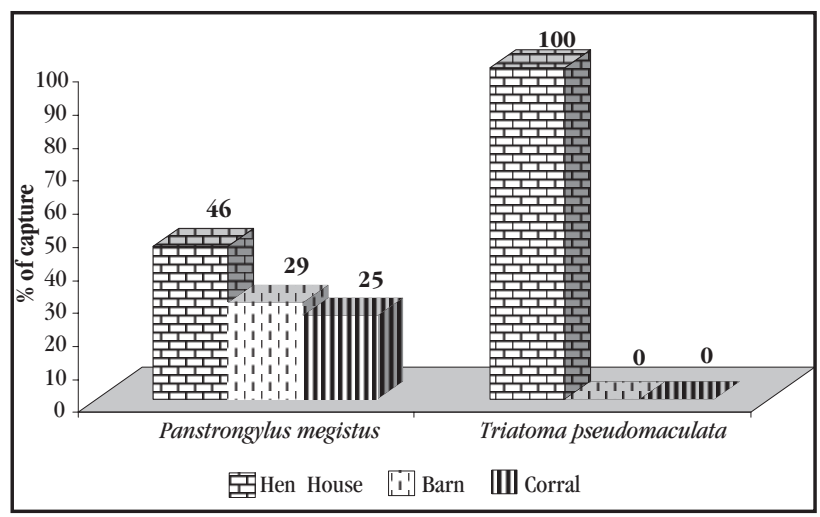

\section{FIGURE 3}

Place where triatomines were captured in the peridomicile of domiciliary units of Berilo municipality, Jequitinhonha Valley, Minas Gerais, during the integrated research program of 2005 .

The presence of triatomines was observed in 28 of the 165 locations examined, with a triatomine dispersion index of $17 \%$. The other entomological indices observed during the study are shown in Table 3.

The majority of DUs in Berilo were of building types A and C. Only a low $(0.4 \%)$ percentage of the houses were in precarious condition (type D). Most of the DUs infested by triatomines were type C (Figure 4 ).
TABLE 3

Entomological indices resultant of the integral research of triatomines in Berilo municipality, Jequitinhonha Valley, MG, Brazil in 2005.

\begin{tabular}{lc}
\hline & Integral research \\
Entomological Index & $\%$ \\
\hline Dispersion index & 17 \\
DU infestation index & 0.7 \\
Intradomiciliary infestation index & 0.1 \\
Peridomiciliary infestation & 0.5 \\
Intradomicile colonization index & 62.5 \\
Peridomicile colonization index & 79.3 \\
Triatominic density & 7.5 \\
\hline
\end{tabular}

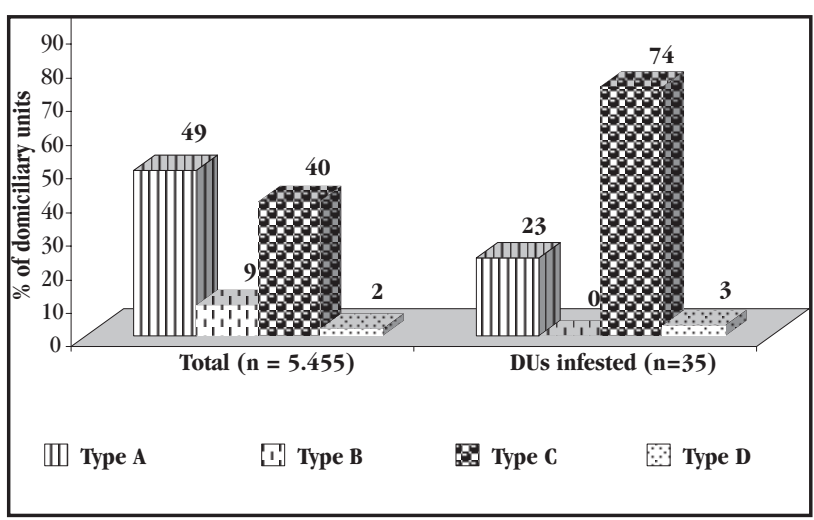

FIGURE 4

Building patterns of domiciliary units in Berilo municipality, Jequitinhonha Valley, Minas Gerais, observed during the integrated triatomine research program: Total and infested domiciliary units.

Prevalence of human Trypanosoma cruzi infection. Blood samples were collected from 124/148 (84\%) of residents of triatomine-infested DUs for Trypanosoma cruzi serological analysis. No-one refused to be examined, but $16 \%$ of individuals were away from home on the sampling days. The results are shown in Table 4.

TABLE 4

Prevalence according to age of positive Trypanosoma cruzi serology in inhabitants of the domiciliary units infested by triatomines in Berilo, Jequitinhonha Valley, MG, Brazil during the integral research of triatomines in 2005.

\begin{tabular}{|c|c|c|c|}
\hline $\begin{array}{l}\text { Age } \\
\text { (years) }\end{array}$ & $\begin{array}{c}\text { Examined } \\
\mathrm{n}\end{array}$ & $\begin{array}{c}\text { Positive } \\
\mathrm{n}\end{array}$ & Percentage \\
\hline$\leq 15$ & 39 & 1 & 2.6 \\
\hline $16-29$ & 22 & 0 & 0.0 \\
\hline $30-49$ & 27 & 7 & 25.9 \\
\hline$\geq 50$ & 36 & 23 & 63.9 \\
\hline Total & 124 & 31 & 25.0 \\
\hline
\end{tabular}

Among the reactive individuals, 19 (61.3\%) were female and $12(38.7 \%)$ male. Only one case was under 30 years-old and the most positive individuals were over 50 .

Environmental changes. Based on the NDVI calculated from the Landsat images, the ground coverage of Berilo municipality changed between 1986 and 2001, most notably outside farmed areas. Areas covered by vegetation in September of 1986 and 2001 respectively are shown in dark grey (Figure 5). Note that agricultural land in the upper left of the image did not change 


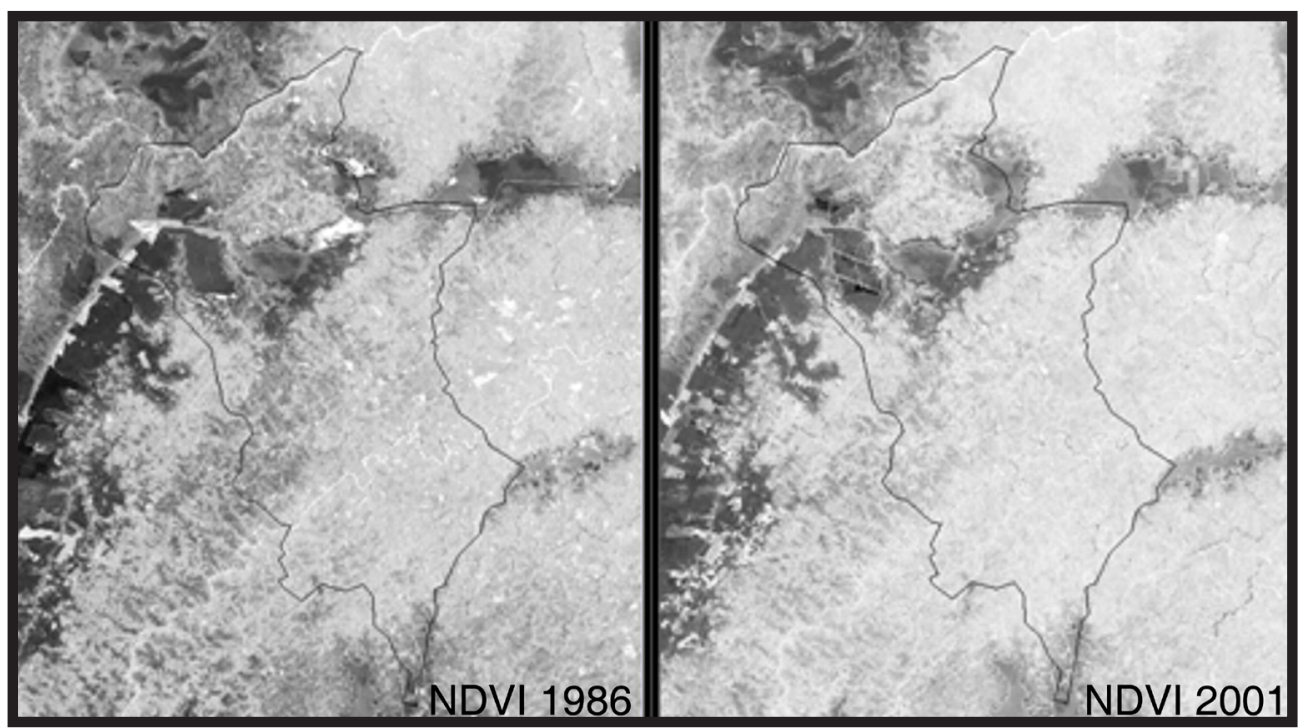

FIGURE 5

Landsat images of the Normalized Difference Vegetation Index (NDVI) in September, 1986 (left) and September, 2001 (right). The darker shade shows the area covered by vegetation. Vegetation was denser and covered more ground in 1986 than in 2001.

much in terms of green coverage; however, farm divisions and man-made structures, such as new roads that appeared by 2001, are easily visible. The most important change occurred in unfarmed lands, where the decrease in green coverage was highly significant $(\mathrm{P}<0.001$, Hodges-Lehmann estimate, Lehmann, 1975). The frequency distribution of the NDVI values for the study area in 1986 and 2001 is shown in Figure 6. The shift in NDVI values to the left of the distribution is noteworthy, i.e., lower NDVI values were more frequent in 2001 than in 1986.



FIGURE 6

Frequency distribution of Normalized Difference Vegetation Index (NDVI) values in 1986 (black bars) and 2001 (white bars). Distributions are significantly different $(\mathrm{P}<0.001$, Hodges-Lehmann estimates, Lehmann 1975) and show that the amount of vegetation coverage decreased between 1986 and 2001.

\section{DISCUSSION}

The triatomine species most frequently captured by local people and health workers during the entomological surveillance and integrated research activities in Berilo was Panstrongylus megistus. This species is endemic to the region and presents a great capacity for reinvasion and recolonization of houses, even after residual spraying with insecticides. Panstrongylus megistus is present in all types of forest outside the Amazon region of Brazil, aridity being the only limiting factor for this species ${ }^{27}$. During the epidemiological surveillance activities, other triatomine species of secondary importance to the epidemiology of Chagas disease were also captured: Triatoma pseudomaculata, Panstrongylus diasi, Panstrongylus geniculatus, Triatoma sordida and Triatoma vitticeps. These insects are present in wild ecotopes and sporadically invade houses, attracted by light and in search of food. Most insects captured during the epidemiological surveillance phase were adult males, mainly in houses. Nymphs were more frequently observed in the peridomicile during the active reseache for triatomines. This suggests that local people find it easier to collect adult insects, which are larger and easier to recognize. This has also been observed in other CDCP areas, such as São Paulo State ${ }^{16}$ and Midwestern Minas Gerais and is an important limitation of epidemiological surveillance that needs to be addressed in workshops and educational materials produced for communities in endemic areas for Chagas disease ${ }^{18}$. Moreover, the local population is not stimulated and a lack of community participation was observed, due in part because epidemiological surveillance activities have not been considered a priority by the municipal authorities.

Infestations by Panstrongylus megistus and Triatoma pseudomaculata were more (81.8\%) prevalent in the peridomicile, an ecotope that presents greater difficulties for chemical control due to the reduced residual effects of the insecticides used. Several authors have demonstrated that insecticides lose their effectiveness due to exposure to light, high temperatures, wind and rain ${ }^{613}$. The peridomicile is also a more complex environment that provides the insects with an abundance of hiding places that are difficult to reach by spraying. Finally, the ample availability of bloodmeal sources makes the peridomicile an excellent place for colonization by Panstrongylus megistus and Triatoma pseudomaculata, especially when the hosts are permanently present, as is the case for hen houses.

In recent years, Triatoma pseudomaculata has increased its presence in and around houses in Berilo, so that by 2005 it was the triatomine species most often captured indoors by local people. 
Its constant presence in the peridomicile, especially in hen houses and eventually in the intradomicile, demonstrates the great adaptive potential of this species and reinforces the need for more effective vector control measures around human dwellings. This increasing presence of Triatoma pseudomaculata in DUs is probably due to environmental and climatic changes that have occurred in the region, such as deforestation, expansion of agricultural areas and increased soil aridity, which favor Triatoma pseudomaculata over Panstrongylus megistus. With the destruction of the original habitat, wild triatomines such as Triatoma pseudomaculata are compelled to migrate. Consequently, this species has moved closer to the DUs, colonizing the peridomicile and subsequently invading houses as demonstrated in this municipality?

The municipality of Berilo presents an accidental topography, including narrow valleys and undulated regions with altimetric levels ranging from 400 to $800 \mathrm{~m}$. The climate is tropical, megathermic, subhumid and dry, with a mean annual temperature of $24^{\circ} \mathrm{C}$. The vegetation is constituted by cerrado and eucalyptus culture was implanted in the north of the municipality.

Evaluation of the recent entomological indices revealed that Berilo municipality presents a lower index of DU infestation, triatomine density and intradomiciliary infestation. However, it is important to note that each triatomine species captured presented a high capacity for colonization of intra- and peridomiciliary environments.

In general, the DUs of Berilo are well-constructed, the majority being built of bricks or adobe tow and tiled roofs. Only a small percentage of houses are in a precarious condition, with adobe without tow providing triatomines with abundant cracks that act as hiding places. The obvious improvement in housing quality observed during the present study, associated with frequent insecticide spraying appears to have effectively controlled intradomiciliary triatomine species, considerably decreasing the risk of Trypanosoma cruzi transmission to man, similar to other endemic areas targeted by the CDCP.

The results of serological tests for Trypanosoma cruzi in inhabitants of triatomine-infested DUs showed most reactive individuals to be older than 30 , corroborating previous data obtained in this municipality ${ }^{12}$. These individuals probably acquired the infection before the implementation of control measures. Only one teenager (aged 15 years) was positive, although she had been identified in previous serological survey performed in the area by our team ${ }^{1}$. Based on the genetic characterization of parasites from this girl and her mother, transmission may have been congenital in this case, since several molecular markers proved to be identical (data not shown). These data on human infection corroborate the findings of Borges et al $^{1}$ in this municipality, where a lower (0.4\%) infection rate was observed in schoolchildren between seven and 14 years-old. Presence of infections in people over 30 years-old suggests that these were based on vectorial transmission, since the Municipal Secretariat of Health has very few reports of blood transfusions in residents of Berilo.

Analysis of the environmental changes shows that green coverage decreased between 1986 and 2001, probably as a consequence of deforestation caused by cattle ranching, reforestation using eucalyptus and/or pineapple cultivation. This decrease in vegetation coverage, increasing the fraction of bare soil, might in turn lead to increases in overall temperature and decreases in relative humidity, all changes that are known to affect populations of triatomine species ${ }^{8}$.

Indications of an interruption in the vectorial transmission of Trypanosoma cruzi in Berilo, such as diminished entomological indices, the absence of acute cases, the rarity of cases of infection in young children and the absence of Triatoma infestans show the need to reinforce the existent surveillance system to consolidate the results obtained so far. The surveillance system must be established permanently to ensure early detection of domestic triatomines and their consequent elimination.

\section{ACKNOWLEDGEMENTS}

The authors would like to thank the municipality of Berilo, José Gonçalves de Minas and the Regional Health Management of Diamantina, MG, for all the facilities provided in conducting this study. The authors are also grateful to the FAPEMIG (announcement CBB 415/03), SESU/MEC and PROEX/UFOP for their financial support. Lana, $M$ and Diotaiuti, L received fellowships from the CNPq.

\section{REFERENCES}

1. Borges JD, Assis GFM, Gomes LV, Dias JCP, Pinto IDM, Martins-Filho AO, Torres RM, Vinãs PA, Bahia MT, Machado-Coelho GLL, Lana M. Seroprevalence of Chagas disease in schoolchildren from two municipalities of Jequitinhonha Valley, Minas Gerais, Brazil, six years following the onset of epidemiological surveillance. Revista do Instituto de Medicina Tropical de São Paulo 48: 81-86, 2006.

2. Carcavallo RU, Girón IG, Juberg J, Lent H. Geographical distribution and altilatitudinal dispersion. In: Carcavallo RU, Girón IG, Juberg J, Lent H (orgs) Atlas dos vetores da Doença de Chagas nas Américas. Fundação Oswaldo Cruz, Rio de Janeiro, vol. III, cap. 17, p.747-793, 1999.

3. Dias JCP. Doença de Chagas em Bambuí, Minas Gerais, Brasil. Estudo clínicoepidemiológico a partir da fase aguda, entre 1.940 e 1.982. Tese de Doutorado, Faculdade de Medicina, Universidade Federal de Minas Gerais, Belo Horizonte, 1982.

4. Dias JCP. The impact of Chagas diseases control in Latin America: a review. Memórias do Instituto Oswaldo Cruz 97: 603-612, 2002.

5. Dias JCP, Diotaiuti L. Small correction, proposal. Revista da Sociedade Brasileira de Medicina Tropical 31: 581-583, 1998.

6. Diotaiuti L, Pinto CT. Suscetibilidade biológica do Triatoma sordida e Triatoma infestans a deltametrina e a lambdacyhalotrina em condições de campo. Revista da Sociedade Brasileira de Medicina Tropical 24: 151-155, 1991.

7. Forattini OP. Biogeografia, origem e distribuição da domiciliação de triatomíneos no Brasil. Revista de Saúde Pública 14: 265-299, 1980.

8. Gorla DE, Catalã SS, Grillo MP. Efecto de la temperatura sobre la distribución de Triatoma infestans y el riesgo de transmisión vectorial de la enfermedad de Chagas en Argentina. Acta Toxicológica Argentina 5: 36-39, 1997.

9. Machado-de-Assis GF, Azeredo BVM, Carbajal de la Fuente AL, Diotaiuti L, Lana M. Domestication of Triatoma pseudomaculata (Côrrea \& Espínola 1964) in the Jequitinhonha Valley of the State of Minas Gerais. Revista da Sociedade Brasileira de Medicina Tropical 40: 391-396, 2007.

10. Martins AV, Versiani V, Tupinambá A. Estudo sobre a Tripanosomíase Americana em Minas Gerais, Brasil. Memórias do Instituto Oswaldo Cruz 35: 285-301, 1940 . 
11. Ministério da Saúde. Normas técnicas para coleta, processamento e transfusão de sangue, componentes e derivados. Diário Oficial da União (Portaria nº 721), 1998

12. Montoya R, Dias JCP, Coura JR. Chagas disease in a community in southeast Brazil. A serologic follow-up study on a vector controlled area. Revista do Instituto de Medicina Tropical de São Paulo 45: 269-274, 2003.

13. Oliveira-Filho AM. New alternatives for the control of triatomines in peridomestic buildings. Revista da Sociedade Brasileira de Medicina Tropical 22: 53-57, 1989

14. Pellegrino J. Novos dados sobre a distribuição de triatomíneos e sua infecção pelo Schizotrypanum cruzi no estado de Minas Gerais, Brasil. Memórias do Instituto Oswaldo Cruz 48: 639-667, 1953.

15. Pinto OS, Bicalho JC, Guedes AS. Contribuição ao conhecimento da distribuiçã̃o geográfica dos triatomíneos domiciliares e de seus índices de infecção natural pelo T. cruzi, no Estado de Minas Gerais, Brasil. Revista Brasileira de Malariologia e Doenças Tropicais 4: 105-122, 1952.
16. Souza AG, Wanderley DMV, Buralli GM, Andrade JCR. Consolidation of the contro of Chagas disease vectors in the state of São Paulo. Memórias do Instituto Oswaldo Cruz 79: 125-131, 1984

17. Sun D, Kafatos M. Note on the NDVI-LST relationship and the use of temperaturerelated drought indices over North America, Geophys. Res. Lett., 34, L24406, doi:10.1029/2007GL031485. 2007.

18. Villela MM, Souza JB, Mello VP, Azeredo BVM, Dias JCP. Vigilância entomológica da doença de Chagas na região centro-oeste de Minas Gerais, Brasil, entre os anos de 2000 e 2003. Cadernos de Saúde Pública 21: 878-886, 2005

19. Voller A, Bidwell DA, Bartlett A. Enzyme immunoassays in diagnostic medicine. Bulletin World Health Organization 53: 55-65, 1976.

20. World Health Organization. Control of Chagas diseases. Geneva: World Health Organization, Technical Report Series $n^{0}$ 811, 1991.

21. World Health Organization. Reporte sobre la enfermedad de Chagas. Grupo de trabajo científico 17-20 abril, 2005 - Actualizado en julio de 2007. Buenos Aires, Argentina. Available at: http://apps.who.int/tdr/svc/publications/tdr-researchpublications/reporte-enfermedad-chagas 